\title{
The Effectiveness of Building Permit Regulation for Green Open Space at Housing Estates: Case Study of Kendal Regency, Central Java, Indonesia
}

\author{
Wiwik Yulianti ${ }^{1}$ and Sudharto P. Hadi ${ }^{1}$ \\ ${ }^{1}$ Master Program of Environmental Studies, School of Postgraduate Studies Diponegoro Univers ity, Semarang - Indonesia
}

\begin{abstract}
Increasing demand for settlements steamed by population growth declines the quality of the environment specifically at urban area. The existing spatial planning could not able to prevent the change of land use for settlement and other infrastructures. The Act no. 26 of 2007 on spatial planning stipulates that green open space must reach $30 \%$ of the total area, consisting of $20 \%$ public open space and $10 \%$ private open space. The existing condition of urban area at Kendal Regency reach 245,6 million $\mathrm{m}^{2}$ with $88.145,5 \mathrm{~m}^{2}$ green open space or $0,036 \%$ out of total area. An effort to increase green open space in urban areas taken by the Government of Kendal Regency is by promulgating a local regulation stipulating that each housing developer request a build ing permit is obliged to provide a green open space at least 10 percent of the total housing area. This paper reviews the effectiveness of building permit regulation, the problems encountered and the concept proposed to make the local regulation work. The area of sample taken is three urban districts out of five urban districts, the resource persons chosen are those from relevant offices (Dinas) involved at the implementation of the local regulation. The data collection techniques employed are the Analytical Hierarchy Process (AHP), Geographic Information System (GIS) technology, social observation and informal interview. The data gathered will be analyzed quantitatively and qualitatively.
\end{abstract}

\section{Introduction}

Physical development as an implication of population grow this inevitable because of the need for the development growth of residential areas, industrial estates, trade and service areas, and supporting facilities such as roads, terminals, ports, airports, etc [1]. The population's need for space for shelter, activities, and activity support is following the rate of population growth in a region.

The change of land use shows an increase in human needs, especially the primary need to build houses. Currently, the provision of housing has become a potential business project [2]. The increase in housing demand is driving the emergence of housing provided by housing developers. Land use change can not be denied occurs in every inch of the city, changing the original area of the natural area into the built area. Green areas are displaced into residential areas.

Therefore, the direction of development is not only focused on the acceleration of economic growth but also on improving the quality of human life through balancing between development and the environment. Development in a region must always consider the social conditions of the population and environmental aspects known as sustainable development. In the world that more urbanized, the need for sustainable urban and residential development is important [3].

The implementation of the concept of sustainable urban development began in the early 1990s, preceded by the UN Conference on Environment and Development (UNCED) in 1992, and the 15th UNCHS in Jakarta 1995, which identifies key sustainable development measures for human settlements. The Commission demonstrates that sustainable development is not only a new way of environmental protection, but a 'new concept of economic growth that ensures justice and opportunity for everyone in the world without destroying natural resources and without reducing the world's carrying capacity'. In 1996, UNCHS or UNHabitat expanded the concept of sustainable development for urban planning. That 'Settlement planning plays an important role to ensure management and urban development achieve sustainable development goals'[4].

The concept of sustainable cities is closely linked to economic development, protection of resources and the environment, which in turn leads to achievement of

*Corresponding author: anti.juli@gmail.com 
acceptable minimum quality of life [5]. And there needs to be an ongoing effort to address the issue of air pollution, congestion, human populations and the availability of green open spaces. A strong, healthy and habitable city depends on a healthy environment, a strong economy and adequate employment opportunities for its citizens [6].

Housing policies should be directed towards achieving sustainable housing development goals. Tolba's statement as quoted by Choguill [5], sustainable housing can be achieved with 4 (four) criteria, that is economically feasible, socially acceptable, technically feasible and environmentally friendly.

Government efforts to accommodate sustainable settlement fulfillment are held through the development of Green Open Space. Urban green open space is one of the important elements of the habitable city [7]. In principle, green open space is intended to suppress the negative effects of urban built environments, such as decreasing the rate of water absorption, increasing air temperature and humidity, pollution, etc. [8].

Increasing demand for settlements steamed by population growth declines the quality of the environment specifically at urban area. The existing spatial planning could not able to prevent the change of land use for settlement and other infrastructures. The Act no. 26 of 2007 on spatial planning stipulates that green open space must reach $30 \%$ of the total area, consisting of $20 \%$ public open space and $10 \%$ private open space. The existing condition of urban area at Kendal Regency reach 245,6 million m2 with 88.145,5 $\mathrm{m} 2$ green open space or $0,036 \%$ out of total area. An effort to increase green open space in urban areas taken by the Government of Kendal Regency is by promulgating a local regulation stipulating that each housing developer request a building permit is obliged to provide a green open space at least 10 percent of the total housing area.

Through the mechanism of the technical requirements of the building permit expected growth of urban green space area following the growth of housing in urban areas, Kendal. The results of Kristianova's research[9] indicated that the supply of green open space in residential areas is often defeated by social and economic interests, such as the development of housing itself (densification) and the development of facilities both commercial services (parking) and community (places of religious activity) Additional facilities previously unplanned during the housing development planning.

This article applies the combination of visualization tools with a specialized analysis method to evaluate the effectiveness of building permit regulation for green open space at housing estates in Kendal Regency, Central Java, Indonesia. This paper reviews the effectiveness of building permit regulation, the problems encountered and the concept proposed to make the local regulation work. The area of sample taken is three urban districts out of five urban districts, the resource persons chosen are those from relevant offices involved at the implementation of the local regulation. The data collection techniques employed are the analytic hierarchy process (AHP), Geographic Information System (GIS) technology, social observation and informal interview. The data gathered will be analyzed quantitatively and qualitatively.

\section{Study Case}

Figures and tables, as originals of good quality and well The area of sample taken is three urban districts out of five urban districts in Kendal Regency, Central Java. The locus of research include: Kendal District, Kaliwungu District, and Weleri District

Three districts in the research samples selected with the justification that the three districts in the corridor of the north coast of Java that in fact the urban level higher than the urban areas are in the southern region of northern coastal road.

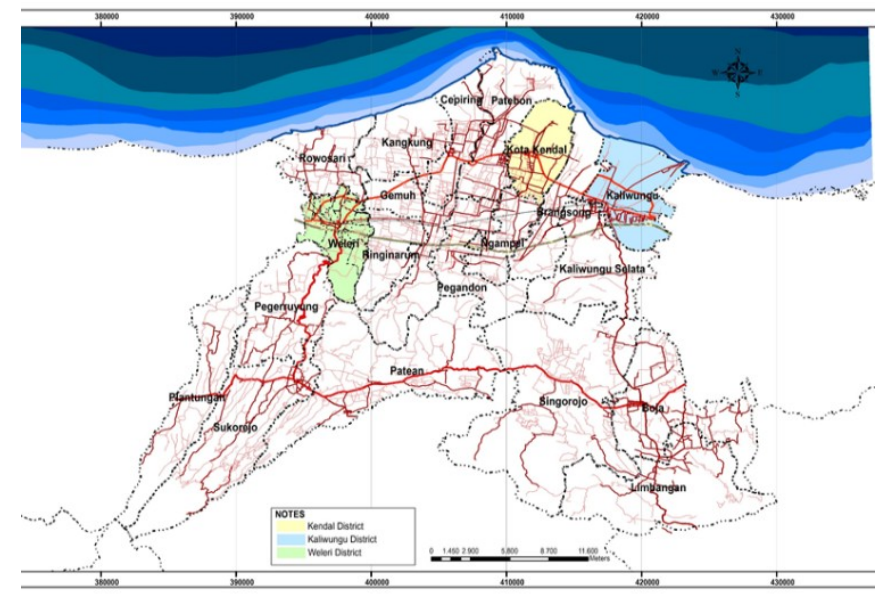

Fig. 1.Case Study Area

\section{Effectiveness Analysis}

The Geographical Information System (GIS) application is used to clarify the visualization of the research object. GIS applications are used to identify housing estates areas and green open spaces in urban areas through delineation green areas with remote sensing data of Upright High Resolution Satellite Imagery of Kendal scale 1: 5000. The results of the calculation of the existing green open spaces of the effectiveness analysis stage.

Measurement of effectiveness is done by adapting the Satries et al. [10] method with the appropriate adjustment of research materials, then the formula used as follows:

\section{Percentage Open SpaceArea \\ The area of green open spacein housing estates Housing Estates Area}




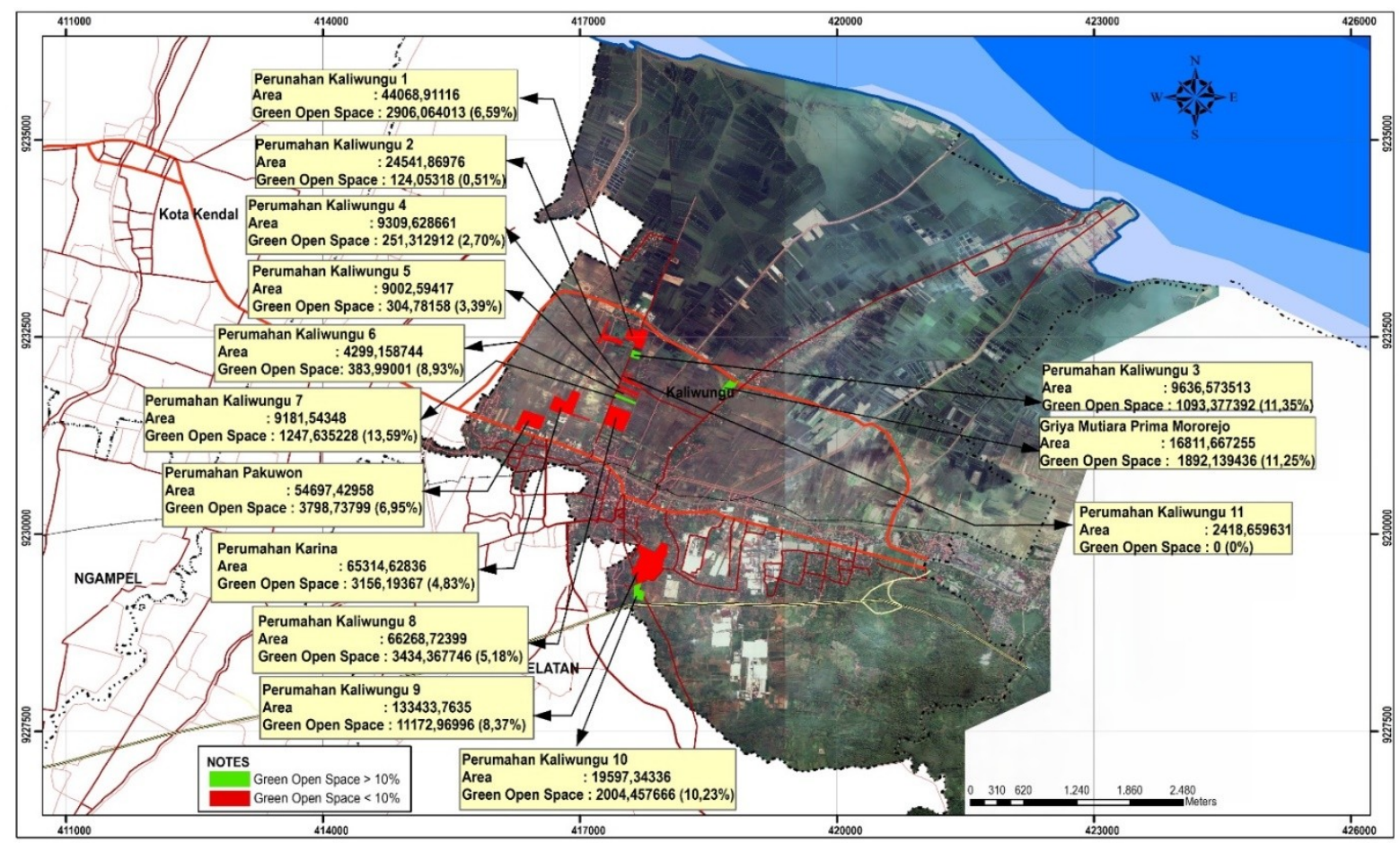

Fig. 2.Housing Area in Kaliwungu District

Table1.Green Open Space Percentage of Housing Estates in Kaliwungu District

\begin{tabular}{|c|c|c|c|c|c|}
\hline No & Housing Estates & $\begin{array}{c}\text { Housing Estates } \\
\text { Area (m2) }\end{array}$ & $\begin{array}{c}\text { Green Open } \\
\text { Space Area } \\
(\mathrm{m} 2) \\
\end{array}$ & $\begin{array}{l}\text { \% Open } \\
\text { Space }\end{array}$ & Note \\
\hline 1 & Perumahan Kaliwungu 11 & $2.418,66$ & 0,00 & 0,00 & $<10 \%$ \\
\hline 2 & Perumahan Kaliwungu 2 & $24.541,87$ & 124,05 & 0,51 & $<10 \%$ \\
\hline 3 & Perumahan Kaliwungu 4 & $9.309,63$ & 251,31 & 2,70 & $<10 \%$ \\
\hline 4 & Perumahan Kaliwungu 5 & $9.002,59$ & 304,78 & 3,39 & $<10 \%$ \\
\hline 5 & Karina & $65.314,63$ & $3.156,19$ & 4,83 & $<10 \%$ \\
\hline 6 & Perumahan Kaliwungu 8 & $66.268,72$ & $3.434,37$ & 5,18 & $<10 \%$ \\
\hline 7 & Perumahan Kaliwungu 1 & $44.068,91$ & $2.906,06$ & 6,59 & $<10 \%$ \\
\hline 8 & Pakuwon & $54.697,43$ & $3.798,74$ & 6,95 & $<10 \%$ \\
\hline 9 & Perumahan Kaliwungu 9 & $133.433,76$ & $11.172,97$ & 8,37 & $<10 \%$ \\
\hline 10 & Perumahan Kaliwungu 6 & $4.299,16$ & 383,99 & 8,93 & $<10 \%$ \\
\hline 11 & Perumahan Kaliwungu 10 & $19.597,34$ & $2.004,46$ & 10,23 & $>10 \%$ \\
\hline 12 & Griya Mutiara Prima Mororejo & $16.811,67$ & $1.892,14$ & 11,25 & $>10 \%$ \\
\hline 13 & Perumahan Kaliwungu 3 & $9.636,57$ & $1.093,38$ & 11,35 & $>10 \%$ \\
\hline 14 & Perumahan Kaliwungu 7 & $9.181,54$ & $1.247,64$ & 13,59 & $>10 \%$ \\
\hline \multicolumn{4}{|c|}{ Average } & \multicolumn{2}{|c|}{6,70} \\
\hline
\end{tabular}

Source: Spatial Analysis, 2017 


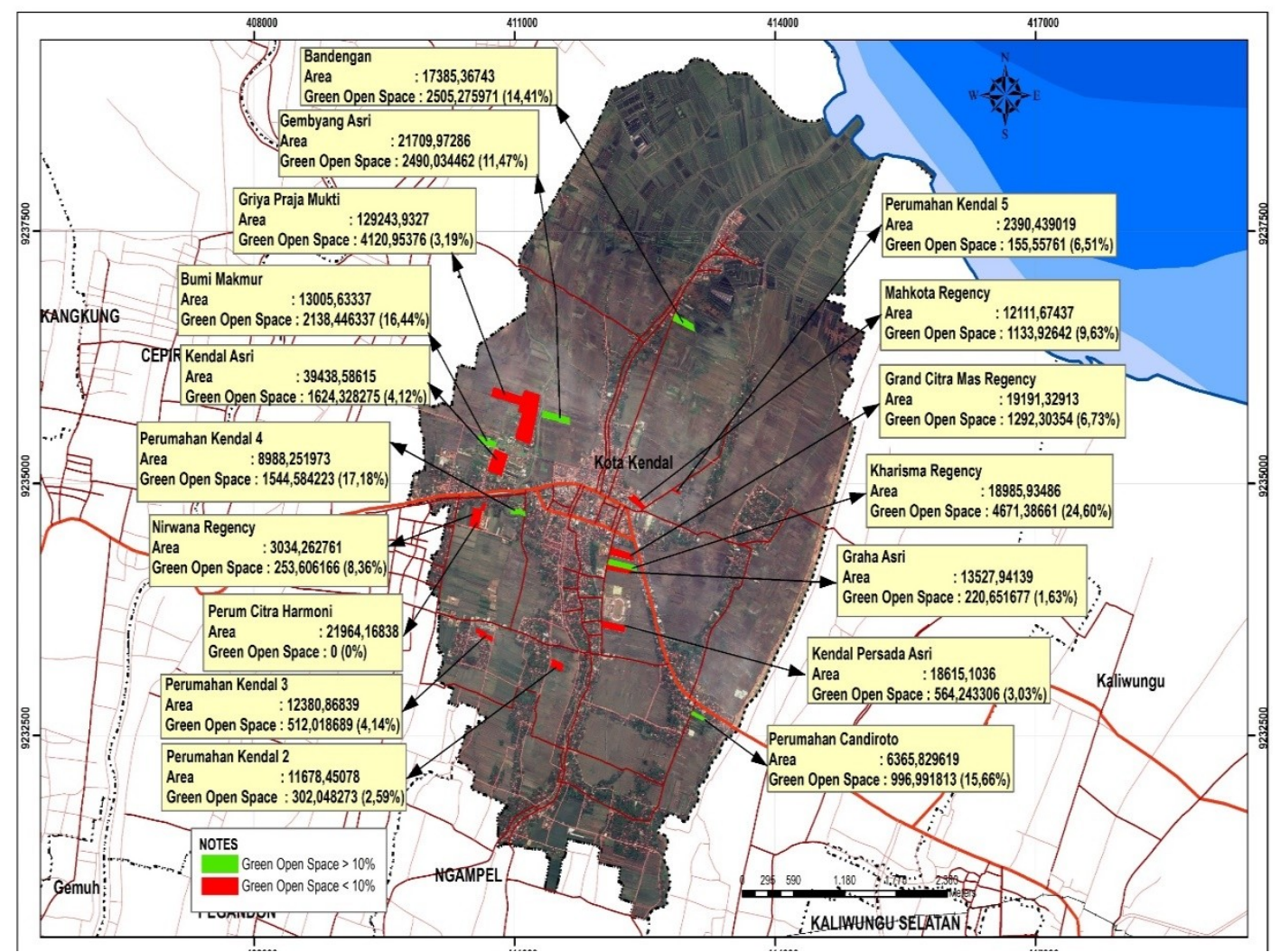

Fig.3.Housing Area in Kendal Kota District

Table2.Green Open Space Percentage of Housing Estates in Kendal Kota District

\begin{tabular}{|c|c|c|c|c|c|}
\hline No & Housing Estates & $\begin{array}{c}\text { Housing Estates } \\
\text { Area (m2) }\end{array}$ & $\begin{array}{c}\text { Green Open } \\
\text { Space Area } \\
(\mathrm{m} 2) \\
\end{array}$ & $\begin{array}{l}\text { \% Open } \\
\text { Space }\end{array}$ & Note \\
\hline 1. & Perum Citra Harmoni & 21964,16838 & 0 & 0,00 & $<10 \%$ \\
\hline 2. & Graha Asri & 13527,94139 & 220,651677 & 1,63 & $<10 \%$ \\
\hline 3. & Perumahan Kendal 2 & 11678,45078 & 302,048273 & 2,59 & $<10 \%$ \\
\hline 4. & Kendal Persada Asri & 18615,1036 & 564,243306 & 3,03 & $<10 \%$ \\
\hline 5. & Griya Praja Mukti & 129243,9327 & 4120,95376 & 3,19 & $<10 \%$ \\
\hline 6. & Kendal Asri & 39438,58615 & 1624,328275 & 4,12 & $<10 \%$ \\
\hline 7. & Perumahan Kendal 3 & 12380,86839 & 512,018689 & 4,14 & $<10 \%$ \\
\hline 8. & Perumahan Kendal 5 & 2390,439019 & 155,55761 & 6,51 & $<10 \%$ \\
\hline 9. & Grand Citra Mas Regency & 19191,32913 & 1292,30354 & 6,73 & $<10 \%$ \\
\hline 10. & Nirwana Regency & 3034,262761 & 253,606166 & 8,36 & $<10 \%$ \\
\hline 11. & Mahkota Regency & 12111,67437 & 1133,92642 & 9,36 & $<10 \%$ \\
\hline 12. & Gembyang Asri & 21709,97286 & 2490,034462 & 11,47 & $>10 \%$ \\
\hline 13. & Bandengan & 17385,36743 & 2505,275971 & 14,41 & $>10 \%$ \\
\hline 14. & Candiroto & 6365,829619 & 996,991813 & 15,66 & $>10 \%$ \\
\hline 15. & Bumi Makmur & 13005,63337 & 2138,446337 & 16,44 & $>10 \%$ \\
\hline 16. & Perumahan Kendal 4 & 8988,251973 & 1544,584223 & 17,18 & $>10 \%$ \\
\hline 17. & Kharisma Regency & 18985,93486 & 4671,38661 & 24,60 & $>10 \%$ \\
\hline \multicolumn{4}{|c|}{ Average } & \multicolumn{2}{|c|}{8,79} \\
\hline
\end{tabular}

Source: Spatial Analysis, 2017 


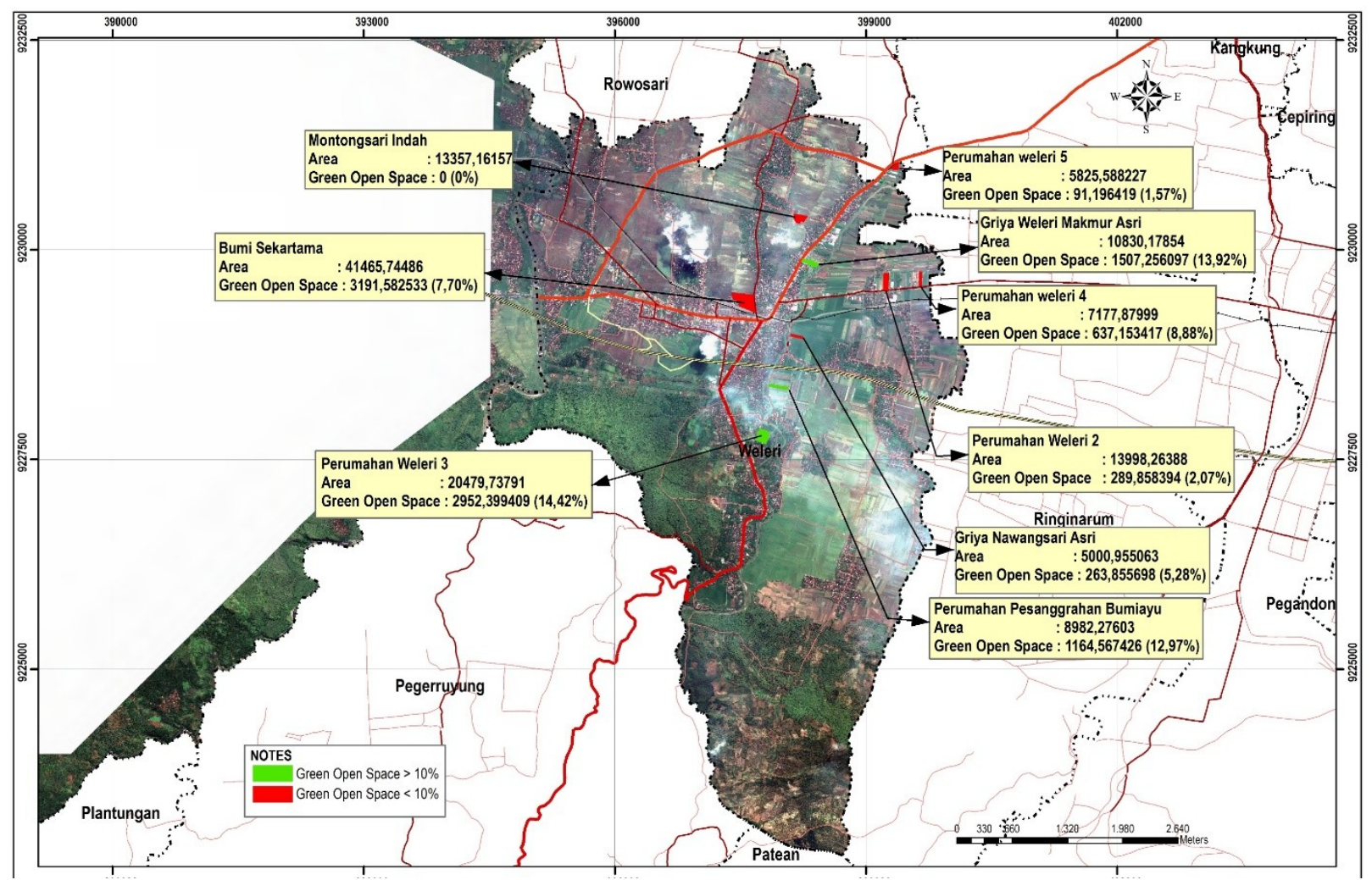

Fig.4.Housing Area in Weleri District

Table3.Green Open Space Percentage of Housing Estates in Weleri District

\begin{tabular}{|c|c|c|c|c|c|}
\hline No & Housing Estates & $\begin{array}{l}\text { Housing Estates } \\
\text { Area }(\mathbf{m} 2)\end{array}$ & $\begin{array}{c}\text { Green Open } \\
\text { Space Area } \\
\text { (m2) }\end{array}$ & $\begin{array}{l}\text { \% Open } \\
\text { Space }\end{array}$ & Note \\
\hline 1. & Montongsari Indah & 13357,16157 & 0 & 0,00 & $<10 \%$ \\
\hline 2. & Perumahan Weleri 5 & 5825,588227 & 91,196419 & 1,57 & $<10 \%$ \\
\hline 3. & Perumahan Weleri 2 & 13998,26388 & 289,858394 & 2,07 & $<10 \%$ \\
\hline 4. & Griya Nawangsari Asri & 5000,955063 & 263,855698 & 5,28 & $<10 \%$ \\
\hline 5. & Bumi Sekartama & 41465,74486 & 3191,582533 & 7,70 & $<10 \%$ \\
\hline 6. & Perumahan Weleri 4 & 7177,87999 & 637,153417 & 8,88 & $<10 \%$ \\
\hline 7. & $\begin{array}{l}\text { Perumahan Pesanggrahan } \\
\text { Bumiayu }\end{array}$ & 8982,27603 & 1164,567426 & 12,97 & $>10 \%$ \\
\hline 8. & Griya Weleri Makmur Asri & 10830,17854 & 1507,256097 & 13,92 & $>10 \%$ \\
\hline 9. & Perumahan Weleri 3 & 20479,73791 & 2952,399409 & 14,42 & $>10 \%$ \\
\hline \multicolumn{4}{|c|}{ Average } & \multicolumn{2}{|c|}{7,42} \\
\hline
\end{tabular}

Source: Spatial Analysis, 2017

The calculation results of the effectiveness of each housing then recapitulated and calculated the average value. Based on Arikuntoat Satries et al., Interpretation of the result of the percentage of the average value refers to the following table .
Table 4.Effectiveness Value Interpretation Standard

\begin{tabular}{|c|l|}
\hline $\begin{array}{c}\text { Number of Green Open } \\
\text { Space Area }<\mathbf{1 0 \%}\end{array}$ & \multicolumn{1}{|c|}{ Value Interpretation } \\
\hline $80 \%-100 \%$ & Very Low \\
$60 \%-79,9 \%$ & Low \\
$40 \%-59,9 \%$ & Rather Low \\
$20 \%-39,9 \%$ & Enough \\
$0 \%-19,9 \%$ & High \\
\hline
\end{tabular}


Table 5. The Result of Effectiveness Value Interpretation

\begin{tabular}{|c|l|c|c|c|c|}
\hline No & District & $\begin{array}{c}\text { Green Open } \\
\text { Space } \mathbf{1 0 \%}\end{array}$ & $\begin{array}{c}\text { Green 0pen } \\
\text { Space }<\mathbf{1 0 \%}\end{array}$ & Percentage & $\begin{array}{c}\text { Effectiveness } \\
\text { Value } \\
\text { Interpretation }\end{array}$ \\
\hline 1 & Kaliwungu & 4 & 10 & 71,43 & Low \\
\hline 2 & Kota Kendal & 6 & 11 & 64,71 & Low \\
\hline 3 & Weleri & 3 & 6 & 66,67 & Low \\
\hline
\end{tabular}

Based on the interpretation of the effectiveness value, the value of building permit effectiveness in the fulfillment of green open spaces of housing estates area can be determined.
Based on spatial analysis it is seen that the three districts have low effectiveness value in enforcement of building permit related to the fulfillment of green open space standard in housing estates area.

\section{Regulation Implementation Effectiveness Strategies}

Strategy formulation combines the corresponding theories such as the effectiveness of law enforcement theory, public policy, and environmental management. The formulation of indicators, criteria, and variables for effectiveness of regulation implementation are as follows.

Table 6. The Formulation of Indicators, Criteria, and Variables for Regulation Implementation Strategies

\begin{tabular}{|c|c|c|c|}
\hline NO & INDICATORS & $\begin{array}{c}\text { CRITERIA } \\
{[11]}\end{array}$ & VARIABLES \\
\hline \multirow[t]{14}{*}{1.} & INPUT ([12],[13],[14]) & A. Organization Characteristics[15] & 1. Institutional Climate([11],[16],[17]) \\
\hline & & & 2. Institutional Goals ([12],[18],[19],[20]) \\
\hline & & & $\begin{array}{l}\text { 3. Institutional Regulation ([17], [19], [21], [22], } \\
[23])\end{array}$ \\
\hline & & & 4. Standard Operating Procedures (SOP) [24] \\
\hline & & & 5. Violation Detection System [25] \\
\hline & & & 6. Source of Budget Funds ([15], [22], [24], [26]) \\
\hline & & & 7. Facilities and Infrastructure ([11], [12],[15],[24]) \\
\hline & & & 8. Incentives dan Dis incentives, ([16],[22], [26]) \\
\hline & & & 9. Sanctions [24] \\
\hline & & B. Actors Characteristics ([19],[21]) & 1. Leadership ([18], [19], [22], [27]) \\
\hline & & & 2. Rational Actors[26] \\
\hline & & & 3. Competence ([3], [22], [26]) \\
\hline & & & 4. The divison of Roles ([3], [11]) \\
\hline & & & 5. Commitment $([11],[15],[18],[19],[26])$ \\
\hline \multirow[t]{11}{*}{2.} & $\begin{array}{l}\text { PROCESS ([12], [13], } \\
[14],[17])\end{array}$ & A. Management Characteristics & 1. Implementation Strategy[12] \\
\hline & & & 2. Instrument Implementation[11] \\
\hline & & & 3. Duty and Authority([3],[23]) \\
\hline & & & 4. Communication ([11],[19],[26]) \\
\hline & & & 5. Coordination $([22],[26])$ \\
\hline & & & 6. Responsiveness[24] \\
\hline & & & 7. Accountabilty $[28]$ \\
\hline & & & 8. Monitoring [12] \\
\hline & & & 9. Evaluation [15] \\
\hline & & $\begin{array}{l}\text { B. Environment Characteristics (Internal } \\
\text { and External) ([12], [19], [21], [27]) }\end{array}$ & 1. Task alignment[12] \\
\hline & & & 2. Alignment of Goals[26] \\
\hline
\end{tabular}




\begin{tabular}{|l|l|l|l|}
\hline NO & INDICATORS & \multicolumn{1}{|c|}{ CRITERIA } \\
{$[11]$}
\end{tabular}

the priority of indicator, criterion, and evaluation

\section{Expert Choice (EC)}

Expert Choice (EC) v11 issued as one of the tools to help decision makers in making decisions. Based on priority assessment by Kendal District Licensing Team, variable of the maturity of the regulation implementation.

Hierarchy of priority assessment of indicators, criteria, and variable assessment of the maturity of regulatory implementation as following fig.

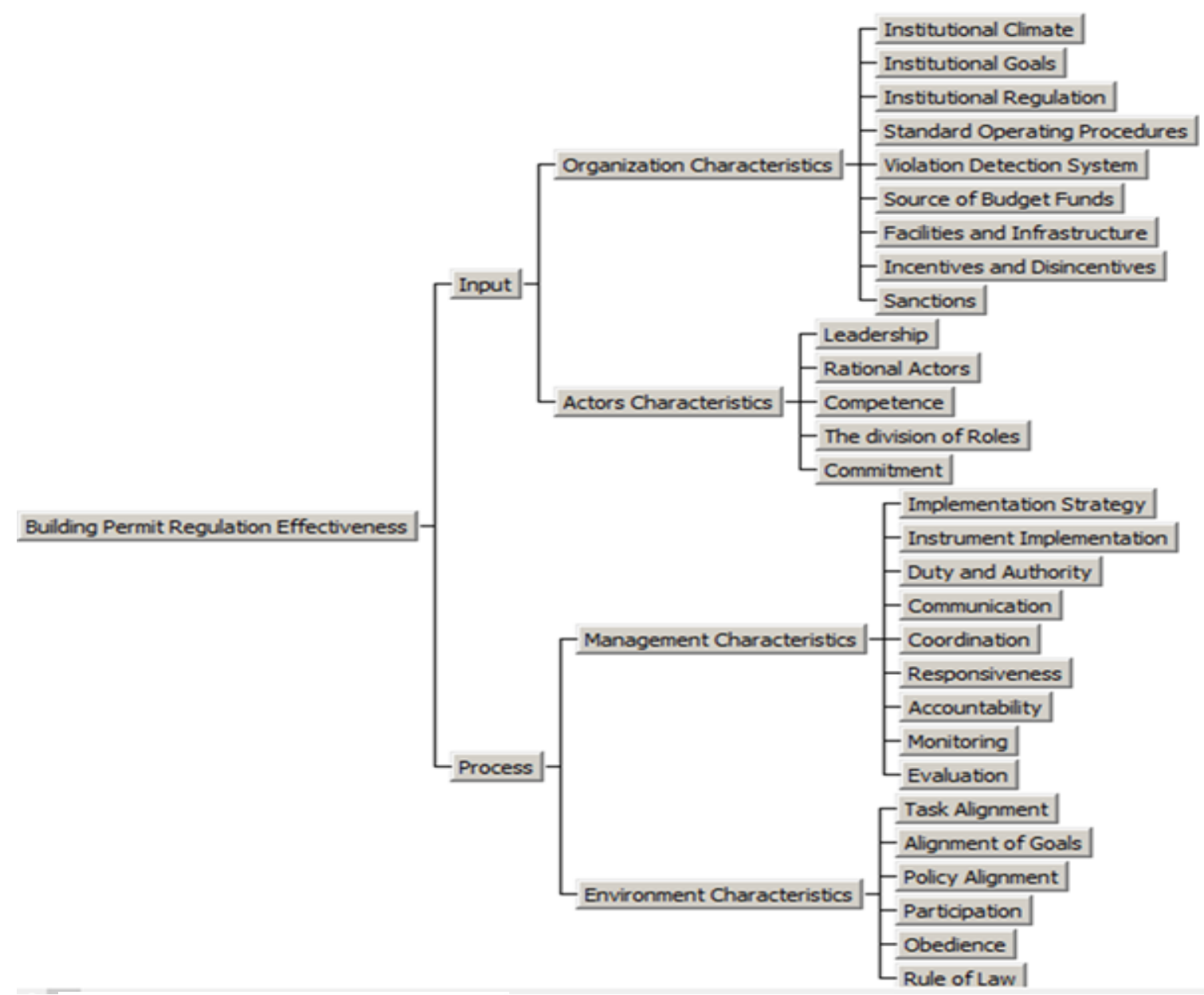

Fig. 5. Hierarchy of Priority Assessment 


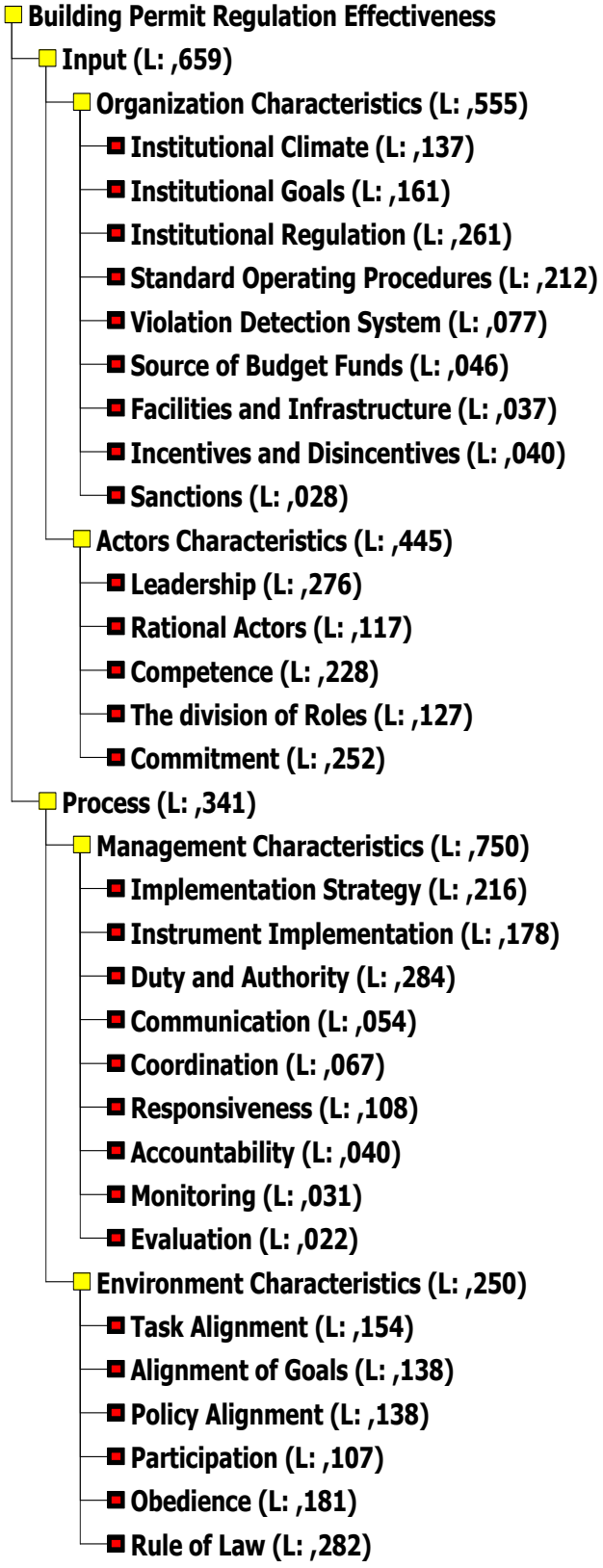

Fig. 6 The Result of AHP

To realize the effectiveness of the implementation of the regulation, the implementation of activities in accordance with the above priority values.

\section{Conclusion}

The conclusions that can be drawn from the above description are:

1. By calculating the priority of indicators, criteria, and variables of maturity regulation implementation above, it can be designed the initial scenario of regulation implementation strategies.
2. In accordance with the results of the study, the effectiveness of building permit regulations in the fulfillment of private green open space standards in residential areas is influenced by input implementation, especially organizational internal characteristics (institutional goals, institutional climate, violation detection system, source of budget funds, incentives and disincentives, facilities and infrastructure, and sanctions). The second factor affecting effectiveness of regulatory implementation is actors characteristics (leadership, commitment, competence, the division of roles, and rational actors).

3. The third and fourth factors affecting the effectiveness of building permit regulations in the fulfillment of private green open space standards in residential areas are part of the implementation process, ie. management characteristics (duty and authority, implementation strategy, instrument implementation, responsiveness, coordination, communication, accountability, monitoring and evaluation). The last factor affecting the effectiveness of regulatory implementation is the factor deriving from the object of the regulation itself, namely Environment Characteristics (ie. rule of law, obedience, task Alignment, alignment of goals, policy alignment, and participation)

\section{References}

1. S. P. Hadi, Manusia dan Lingkungan, Cetakan II. Semarang: Badan Penerbit Universitas Diponegoro (2013)

2. B. Widodo, R. Lupyanto, B. Sulistiono, D. A. Harjito, J. Hamidin, E. Hapsari, M. Yasin, and C. Ellinda, "Analysis of environmental carrying capacity for the development of sustainable settlement in Yogyakarta urban area," Procedia Environ. Sci., vol. 28, no. SustaiN 2014, pp. 519$\mathbf{5 2 7}$ (2015)

3. L. Smeddle-Thompson, "Implementing Sustainable Human Settlements," Stellenbosch University (2012)

4. UN-Habitat, "Planning Sustainable Cities: Global Report on Human Settlements 2009," London (2009)

5. C. L. Choguill, "The search for policies to support sustainable housing," Habitat Int., vol. 31, no. 1, pp. 143-149(2007)

6. C. V Katju, "Sustainable Cities," Vol. 10 No. 7 July (2000). [Online]. Available: http://www.devalt.org/newsletter/jul00/lead.htm. [Accessed: 07-May-2017].

7. C. Y. Jim and S. S. Chen, "Comprehensive greenspace planning based on landscape ecology principles in compact Nanjing city, China," Landsc. Urban Plan., vol. 65, no. 3, pp. 95116(2003)

8. Hasni, Hukum Penataan Ruang dan Penatagunaan Tanah dalam Konteks UUPAUUPR-UUPPLH, Ed. 3, Cet. Jakarta: Rajawali 
Pers (2016)

9. K. Kristianova, "Post-Socialist Transformations of Green Open Spaces in Large Scale Socialist Housing Estates in Slovakia," Procedia Eng., vol. 161, pp. 1863-1867 (2016)

10. W. I. Satries, "Efektivitas Program Pemberdayaan Pemuda pada Organisasi Kepemudaan Al Fatih Ibadurrohman Kota Bekasi," Universitas Indonesia (2011)

11. T. W. Steers, Richard M and Lee, "Facilitating Effective Performance Appraisals: The Role of Employee Commitment and Organizational Climate," in Performance Measurement and Theory, New Jersey: Lawrence Erlbaum Associates, Inc(1983), pp. 75-87.

12. S. Oberthür and L. Groen, "The Effectiveness Dimension of the EU's Performance in International Institutions: Toward a More Comprehensive Assessment Framework," J. Common Mark. Stud., vol. 53, no. 6, pp. 13191335 (2015)

13. P. Sparrow and C. Cooper, "Organizational effectiveness, people and performance: new challenges, new research agendas," J. Organ. Eff. People Perform., vol. 1, no. 1, pp. 2-13 (2014)

14. S. A. Hejazi and K. R. Jackson, "A neural network approach to efficient valuation of large portfolios of variable annuities," Insur. Math. Econ., vol. 70, pp. 169-181 (2016)

15. J. L. Harrison, 'Bureaucrats' Tacit Understandings and Social Movement Policy Implementation: Unpacking the Deviation of Agency Environmental Justice Programs from EJ Movement Priorities," Soc. Probl., vol. 63, no. 4, pp. 534-553 (2016)

16. J. Wallner, "Legitimacy and Public Policy: Seeing Beyond Effctiveness, Efficiancy and Performance," Policy Stud. J., vol. 36, no. 3, pp. 421-443(2008)

17. R. L. Glicksman, "Effectiveness of Government Interventions at Inducing Better Environmental Performance: Does Effectiveness Depend on Facility or Firm Features?," Coll. Environ. Aff.
Law Rev., vol. 35, no. 3, pp. 479-512 (2008)

18. P. Sabatier and D. Mazmanian, "THE IMPLEMENTATION OF PUBLIC POLICY :," (1979)

19. P. Hill, Michael and Hupe, Implementing Public Policy. London: SAGE Publications Ltd(2002)

20. M. Watiah, "Efektivitas Pembinaan Dinas Pengelolaan Pasar Terhadap Pedagang Kaki Lima di Kota Bandar Lampung (Studi pada Pasar Bambu Kuning Kota Bandar Lampung," Universitas Lampung (2011).

21. S. Maryati, "Conceptual Model of Green Infrastructure Implementation," in Proceeding International Seminar Innovations in Accelerating Infrastructure Competitiveness and Sustainability, pp. 51-58(2014)

22. C. Li, J. Li, M. Liu, Y. Wang, and Z. Wu, "Antimisconduct policies, corporate governance and capital market responses: International evidence," J. Int. Financ. Mark. Institutions Money(2016)

23. UKP4, "Strategi Pemberantasan Kejahatan Kebakaran Hutan dan Lahan," no. November, pp. 1-23 (2014)

24. A. Syaprillah, "Penegakan hukum administrasi lingkungan melalui instrumen pengawasan," Bina Huk. Lingkung., vol. Volume 1, no. 32, pp. 99113 (2016)

25. T. Badjuri, Abdulkahar dan Yuwono, Kebijakan Publik Konsep dan Strategi. Semarang: Universitas Diponegoro (2002)

26. M. Juntti, D. Russel, and J. Turnpenny, "Evidence, politics and power in public policy for the environment," Environ. Sci. Policy, vol. 12, no. 3, pp. 207-215(2009)

27. D. N. Bengston, J. O. Fletcher, and K. C. Nelson, "Public policies for managing urban growth and protecting open space: Policy instruments and lessons learned in the United States," Landsc. Urban Plan., vol. 69, no. 2-3, pp. 271-286 (2004)

28. Tachjan, Implementasi Kebijakan Publik. Bandung: AIPI Bandung (2006) 